\title{
ISOLATION AND CHARACTERISTICS OF BOVINE SKIN GELATIN AND ANALYSIS OF GLYCINE, PROLINE, AND HYDROXYPROLINE BY HIGH-PERFORMANCE LIQUID CHROMATOGRAPHY- FLUORESCENCE
}

\author{
DINI KHOIRUNNISA, HARMITA*, TAUFIQ INDRA RUKMANA
}

Department of Pharmacy, Faculty of Pharmacy, Universitas Indonesia, Depok, 16424, Indonesia. Email: igakadeharmita@gmail.com Received: 25 May 2018, Revised and Accepted: 11 October 2018

ABSTRACT

Objective: This study aimed to isolate gelatin, determine its characteristics, and obtain analytical methods optimum for the determination of glycine, proline, and hydroxyproline levels in bovine gelatin.

Methods: Bovine hide was hydrolyzed using $2 \%$ sodium hydroxide at an extraction temperature of $70^{\circ} \mathrm{C}$ for $3 \mathrm{~h}$ and a drying temperature of $60^{\circ} \mathrm{C}$. Then, the gelatin extracts were evaluated using an organoleptic test; Fourier transform infrared analysis; $\mathrm{pH}$ measurement; and ash content, moisture content, and viscosity tests. Optimum analysis conditions for the determination of glycine, proline, and hydroxyproline levels in bovine gelatin using high-performance liquid chromatography with a fluorescence detector were as follows: Excitation wavelength, $265 \mathrm{~nm}$; emission wavelength, $320 \mathrm{~nm}$; mobile phase composition of acetic buffer: acetonitrile, 55:45; flow rate, $0.8 \mathrm{~mL} / \mathrm{min}$; C18 column with length $250 \mathrm{~mm}$ and inner diameter $4.6 \mathrm{~mm}$; and particle size, $5 \mu \mathrm{m}$. Derivatization of amino acids was performed using the reagent 9-fluorenylmethoxycarbonyl chloride.

Results: The results showed average levels of glycine, proline, and hydroxyproline in bovine gelatin, i.e., $25.10 \pm 0.09 \%, 14.28 \pm 0.11 \%$, and $13.0 \pm 0.05 \%$, respectively.

Conclusion: The optimum conditions for bovine gelatin hydrolysis included $\mathrm{HCl}$ with heating for $22 \mathrm{~h}$ at $110^{\circ} \mathrm{C}$. The hydroxyproline, glycine, and proline levels obtained for analysis in bovine gelatin samples were $13.50 \pm 0.05 \%, 25.11 \pm 0.09 \%$, and $14.28 \pm 0.11 \%$, respectively.

Keywords: Bovine gelatin, Glycine, Proline, Hydroxyproline, Derivatization, 9-fluorenyl-methoxycarbonyl chloride, High-performance liquid chromatography, Optimization.

(c) 2018 The Authors. Published by Innovare Academic Sciences Pvt Ltd. This is an open access article under the CC BY license (http://creativecommons. org/licenses/by/4. 0/) DOI: http://dx.doi.org/10.22159/ijap.2018.v10s1.60

\section{INTRODUCTION}

The protein gelatin is produced by hydrolysis of collagen by an acid or alkali. Sources of gelatin feedstock include the skin, bones, and connective tissue (tendons) of farm animals, such as pigs and cattle. Gelatin can show a reversible change in sol-gel form with a change in temperature, form a gel, affect the viscosity of a material, expand in cold water, and protect the colloidal system [1].

In Indonesia, the need for gelatin has significantly increased annually from 2012 to 2016. However, Halal issues become a question for Muslim, considering that imported raw gelatin is believed to be derived from the skin and bones of pigs. This material causes problems for Muslim majority countries, such as Indonesia, because pigs are forbidden for consumption. Therefore, gelatin produced from the skin and bones of bovines has a great potential in the trade sector [2].

Bovine hide has high potential to be processed into gelatin. The spread of collagen in mammalian skin tissue is highest (89\%) compared with other tissues, such as bone, tendon, and muscle [2]. Therefore, this study used bovine hide-based material to produce gelatin.

In this study, gelatin was extracted using $2 \% \mathrm{NaOH}$. The gelatin obtained was characterized based on $\mathrm{pH}$, organoleptic properties, moisture, ash content, viscosity, and functional group analyses using Fouriertransform infrared (FTIR) spectra [3-5].

The composition of amino acids in gelatin differs depending on each animal tissue source, but it always contains large amounts of glycine, proline, and hydroxyproline. In pig gelatin, the glycine, proline, and hydroxyproline levels are higher than in bovine gelatin [6]. Therefore, the determination of glycine, proline, and hydroxyproline levels in the amino acids present in gelatin becomes important to provide information for determining the gelatin source.

Gelatin was extracted from bovine hide by pre-column derivatization using the reagent 9-fluorenyl-methoxycarbonyl chloride (FMOC-Cl), and the result was confirmed with a fluorescence detector. $\mathrm{FMOC}-\mathrm{Cl}$ is capable of derivatizing primary and secondary amino acids, so it can be used in the analysis of glycine, proline, and hydroxyproline. Its FMOC-Cl produces good analytical results with high sensitivity. After the gelatin extraction processes, glycine, proline, and hydroxyproline in analysis was performed.

In this study, we selected high-performance liquid chromatography (HPLC) with a fluorescence detector, which is more effective and selective in amino acid quantification. In addition, HPLC tools are considered more economical and easy to use and are widely available in laboratories and pharmaceutical and food industries. In addition, on the basis of the results of its analysis, a fluorescence detector is considered more sensitive compared with ultraviolet (UV) detectors.

\section{MATERIALS AND METHODS}

Materials

The material used in the study was bovine hide samples from the Cisalak shelter market, Cimanggis Subdistrict, Depok, Indonesia. The chemicals used included standard gelatin from bovine skin type B (Sigma-Aldrich), amino acid standard L-glycine (Gly) (Sigma-Aldrich), trans-4-hydroxy-L-proline (Sigma-Aldrich), and standard L-proline amino acid (Sigma-Aldrich). The derivatization reagents included FMOC-Cl (Hangzhou Dingyan Chem Co.), aquabidest (PT Ikapharmindo 
Putramas, Jakarta, Indonesia), Aqua Pro Injection (PT Ikapharmindo Putramas), Acetonitrile Pro HPLC (Merck), Methanol Pro HPLC (Merck), chloride acid (Merck), sodium hydroxide (Merck), boric acid (Merck), sodium acetate (Merck), and glacial acetic acid (Merck).

The HPLC instrument used in this study was Shimadzu LC-20AT equipped with a pump, a YMC-YMC-Triart ${ }^{\circledR}$ C18 $(250 \times 4.6 \mathrm{~mm}, 5 \mu \mathrm{m})$ column, an RF 20A fluorescence detector (Shimadzu, Japan), an injector (Shimadzu UV-1601), a KCKT syringe (Hamilton), filter paper (SGE, Australia), FTIR spectroscopy no. 40 (Whatman), Millipore $0.45 \mu \mathrm{m}$ (Whatman), analytical scales, a measuring Erlenmeyer flask, stative, clamps, and glassware.

\section{Methods}

\section{Preparation of bovine skin for gelatin extraction}

The raw material used was brown bovine neck hide obtained from the Brahman crossbred (BX) cow. Fur and fat were removed with a sharp knife. The bovine hide cleaned of fur and fat was washed with running water until clean. Then, the hide was cut into sheets, placed into a plastic bag that was then tightly closed, and stored in a refrigerator. These hide sheets were used to prepare gelatin.

\section{Extraction of gelatin from bovine hide}

Gelatin hydrolysis was performed by the alkaline method. Raw bovine hide sheets were weighed to calculate the wet weight. Then, the hide was immersed in $2 \% \mathrm{NaOH}$ solution for $48 \mathrm{~h}$ at $5^{\circ} \mathrm{C}$. The hide sheets were separated and brought to a neutral $\mathrm{pH}$. Then, the hide was filtered and weighed again, placed into an Erlenmeyer flask, and subsequently placed in a water bath at $70^{\circ} \mathrm{C}$ for $3 \mathrm{~h}$ with a hide: water ratio of $1: 3$. The volume of the filtrate was then measured, and it was concentrated with an evaporator for $1 \mathrm{~h}$. Next, it was cooled in the refrigerator for $2 \mathrm{~h}$. The liquid gelatin obtained was poured into a vapor plate and dried in an oven at $60^{\circ} \mathrm{C}$ for $24 \mathrm{~h}$. Finally, the solid gelatin formed was smoothed in a blender to obtain gelatin powder. The gelatin powder was weighed to calculate the value of the immersion obtained.

\section{Characteristics of extracted gelatin}

\section{Analysis of functional groups}

Functional group analysis was performed on standard bovine gelatin and its extracted samples. Standard bovine gelatin and gelatin samples were similarly prepared as explained before. To $2 \mathrm{mg}$ standard bovine gelatin powder, $100 \mathrm{mg}$ of $\mathrm{KBr}$ was added, and the mixture was crushed in a mortar until homogeneous. Then, the mixture was placed in a cup until the cup was full. The cup was placed on a spectroscopy tool equipped with a diffuse reflectance system DRS-8000 for analysis.

\section{Organoleptic observations of shape, color, and smell}

The organoleptic features of gelatin were observed using the methods established by the Indonesian National Standard (SNI) 01-3735-1995. The gelatin produced was observed for its solid form, color, and odor.

\section{pH measurement}

The $\mathrm{pH}$ value of the gelatin solution was measured by the Gelatin Manufacturers Institute of America (GMIA) method [1]. Gelatin solution was prepared at a concentration of $1.5 \%(\mathrm{w} / \mathrm{v})$ using a heated aquadest at $45 \pm 0.5^{\circ} \mathrm{C}$ and up to a sufficient volume of $100 \mathrm{~mL}$. The solution was allowed to stand at room temperature $\left(25^{\circ} \mathrm{C}\right)$. The $\mathrm{pH}$ value was measured using the Eutech Instruments $\mathrm{pH}$ meter.

\section{Measurement of ash content}

The ash content of gelatin was measured by the GMIA method [1]. Approximately $2 \mathrm{~g}$ of gelatin powder was placed in a porcelain cup that had been preheated to incandescence. The cup was placed in a shrinking furnace at a temperature of $600^{\circ} \mathrm{C}$ for 7 . Then, the cup containing the gelatin powder was cooled in a desiccator for $30 \mathrm{~min}$ and weighed until a fixed weight was obtained. The weight decrease percentage was calculated as the percentage ash content.

\section{Measurement of water content}

Water content was also measured by the GMIA method [1]. A closed glass bottle previously dried until its weight was constant was used. Approximately $1 \mathrm{~g}$ gelatin powder was placed in the bottle, which was then placed in an oven at a temperature of $105^{\circ} \mathrm{C}$ for $5-6 \mathrm{~h}$ or until a constant weight was obtained. The bottle containing the gelatin powder was cooled in a desiccator for $30 \mathrm{~min}$ until the weight was constant. The weight decrease percentage was calculated as the percentage water content.

\section{Measurement of viscosity}

Gelatin viscosity was measured by the GMIA method [1]. Gelatin solution was prepared at a concentration of $6.67 \%(\mathrm{w} / \mathrm{v})$ using a heated aquadest at $60^{\circ} \mathrm{C}$. The gelatin solution was allowed to cool to $30 \pm 0.5^{\circ} \mathrm{C}$. The viscosity (centipoise) of $100 \mathrm{~mL}$ gelatin solution was measured using an Ostwald viscometer.

\section{Optimum analysis conditions for glycine, proline, and hydroxyproline} Determination of hydrolysis time of standard gelatin

Approximately $50 \mathrm{mg}$ of standard bovine gelatin was placed in a suitable container and mixed with $5 \mathrm{~mL}$ of $6 \mathrm{~N}$ HCL solution. The mixture was incubated in an oven at $110^{\circ} \mathrm{C}$ for 22,23 , and $24 \mathrm{~h}$. After cooling, $50 \mathrm{mg}$ samples were acquired and dissolved in up to $50 \mathrm{~mL}$ aquabidest to obtain a standard solution concentration of 1000 ppm gelatin. The sample was made homogeneous before derivatization.

\section{Determination of the optimum wavelength for analysis}

A $300 \mu \mathrm{L}$ standard amino acid solution (hydroxyproline, glycine, and proline) with a concentration of $10 \mathrm{ppm}(0.076 \mathrm{mM})$ was added to $300 \mu \mathrm{L}$ of $10 \mathrm{mM}$ borate buffer (pH 9.3). Then, $300 \mu \mathrm{L}$ of $1.5 \mathrm{mM}$ FMOC-Cl (in acetonitrile) was added. After derivatization, the samples were tested using ultraviolet-visible spectrophotometry to obtain the maximum wavelength excitation and optimized wavelength using HPLC with normal analysis conditions at wavelengths of 320,325 , and $330 \mathrm{~nm}$. Notably, the selected wavelengths produced the largest peak areas.

\section{Selection of mobile phase composition}

A $300 \mu \mathrm{L}$ standard bovine gelatin solution was added to $300 \mu \mathrm{L}$ of $10 \mathrm{mM}$ borate buffer ( $\mathrm{pH}$ 9.3). Then, $300 \mu \mathrm{L}$ of $1.5 \mathrm{mM}$ FMOC-Cl (in acetonitrile) was added. After derivatization, $20 \mu \mathrm{L}$ of the sample was injected into the HPLC tool with varying acetate buffer phase (pH 4.2):acetonitrile concentration ratios of 55:45, 60:40, and 65:35; the flow rate was $0.8 \mathrm{~mL} / \mathrm{min}$.

Analysis results obtained from each combination of mobile-phase concentrations were compared. Optimum conditions of analysis were assessed on the basis of separation between two adjacent peaks or resolution $(R)$, peak sharpness, factor follow (Tf), peak release retention time, and column efficiency (number of theoretical plates [N] and height equivalent to the theoretical plate [HETP]).

\section{Selection of flowing phase of motion for analysis}

A $300 \mu \mathrm{L}$ standard bovine gelatin solution was added to $300 \mu \mathrm{L}$ of $10 \mathrm{mM}$ borate buffer (pH 9.3). Then, $300 \mu \mathrm{L}$ of $1.5 \mathrm{mM} \mathrm{FMOC-Cl} \mathrm{(in}$ acetonitrile) was added. After derivatization, $20 \mu \mathrm{L}$ of the sample was injected into the HPLC tool with varying flow rates of the mobile phase (at a selected motion phase composition): $0.8,1.0$, and $1.2 \mathrm{~mL} / \mathrm{min}$.

Analysis results obtained from each combination of the mobile-phase concentrations were compared. Optimum conditions of analysis were assessed on the basis of separation between two adjacent peaks or resolution (R), peak sharpness, Tf, peak release retention time, and column efficiency ( $\mathrm{N}$ and HETP). 


\section{System compatibility test}

A $300 \mu \mathrm{L}$ standard bovine gelatin solution was added to $300 \mu \mathrm{L}$ of $200 \mathrm{mM}$ borate buffer (pH 9.3). Then, $300 \mu \mathrm{L}$ of $1.5 \mathrm{mM}$ FMOC-Cl (in acetonitrile) was added. After derivatization, $20 \mu \mathrm{L}$ of the sample was injected into the HPLC tool six times under selected conditions. The parameters analyzed included separation between two adjacent peaks or resolution (R), peak sharpness, Tf, peak release retention time, and column efficiency ( $\mathrm{N}$ and HETP).

Manufacture of calibration curve, linearity test, limit of detection (LOD), and limit of quantitation (LOQ)

Manufacture of calibration curve and linearity test

The calibration curve test solution was prepared using a mixture of standard amino acid solutions of proline, glycine, and hydroxyproline made in the concentration ranges of $1,2,4,5,10$, and $20 \mu \mathrm{g} / \mathrm{mL}$. Further derivatization was performed in accordance with sample preparation. Then, $20 \mu \mathrm{L}$ of each solution was injected into the HPLC tool under selected analysis conditions. The parameters analyzed included regression of the peak area (y) to analyte concentration (x), and a calibration curve was prepared. The correlation coefficient $(r)$ of the linear regression equation was calculated to observe the linearity of the curve obtained before.

\section{Determination of $L O D$ and $L O Q$}

From the calibration curve obtained, the smallest detectable concentration (LOD) that could still be quantitatively detected (LOQ) was calculated using statistical calculations from the linear regression line of the calibration curve.

\section{Determination of amino acid levels in bovine gelatin samples}

A 5-g gelatin sample was placed in a suitable container and mixed with $5 \mathrm{~mL}$ of $6 \mathrm{~N} \mathrm{HCl}$. The mixture was incubaSted in an oven at $110^{\circ} \mathrm{C}$ for $22 \mathrm{~h}$. After cooling, $50 \mathrm{mg}$ samples were taken and dissolved in $50 \mathrm{~mL}$ aquabidest to obtain a solution concentration of $1000 \mathrm{ppm}$ gelatin. A $300 \mu \mathrm{L}$ of bovine gelatin sample was added to $300 \mu \mathrm{L}$ of $10 \mathrm{mM}$ borate buffer ( $\mathrm{pH}$ 9.3) for further derivatization. Then, $300 \mu \mathrm{L}$ of $1.5 \mathrm{mM}$ FMOC$\mathrm{Cl}$ (in acetonitrile) was added. After derivatization, $20 \mu \mathrm{L}$ of the sample was injected into the HPLC tool under selected analysis conditions, and the resulting peak was analyzed. The triplo test was performed for each sample.

\section{RESULTS AND DISCUSSION}

\section{Gelatin extraction using alkaline hydrolysis}

The process of preparing gelatin began with preparing the bovine hide raw material. The hide was cut into sheets to expand the surface of the material submerged in the solution so that the extraction process could be faster and could produce good-quality gelatin. In the alkaline hydrolysis reaction, the double-helical structure of collagen (three double-helical bonds) is destroyed because of excess $-\mathrm{OH}$ ions. The alkaline hydrolysis reaction was carried out by immersing the hide in $2 \%$ sodium hydroxide for $48 \mathrm{~h}$ at $5^{\circ} \mathrm{C}$ [7]. After hydrolysis, the $\mathrm{pH}$ of the hide became alkaline. The $\mathrm{pH}$ was neutralized by washing the alkaline hide with running water. The weight increased by 2 times, indicating that the hydrolysis was successful. As the collagen structure of the hide was damaged, physically, the hide looked fluffy and clean. It was ready to be further processed to extract gelatin using water at a temperature of $70^{\circ} \mathrm{C}$. When the extracting solution temperature reached $70^{\circ} \mathrm{C}$, the hide returned to its original size or became even smaller, indicating that the gelatin had moved to the aquabidest solution. The gelatin solution was filtered, its volume was measured, and it was concentrated with an evaporator for $1 \mathrm{~h}$. It was cooled until a gelatin gel was formed. The drying process was carried out to obtain solid gelatin with hygroscopic properties, which softened when placed in the open (hereinafter called bovine gelatin). The obtained rendement value was $8.75 \%$. Rendement is the percentage of gelatin calculated on the basis of the ratio of the gelatin produced and the weight of raw material (bovine hide) that had been cleaned and cut into sheets.

\section{Evaluation of the results of bovine hide gelatin extraction}

\section{Organoleptic observations of shape, color, and odor}

Organoleptic characteristics are the physical properties of a substance that can be seen by the naked eye, so the first evaluation of any substance is always organoleptic. The sample gelatin was in the form of a fine powder, while the standard gelatin powder was rough; this texture depends on the smoothing process performed. The sample gelatin and standard gelatin both were pale yellow. The odor of the sample gelatin was fishier than the standard gelatin.

\section{Analysis of functional groups}

The typical gelatin absorption peak curve has four parts:

i. An amide group: The absorption region at a $3600-2300 \mathrm{~cm}^{-1}$ wavelength indicates the presence of an $\mathrm{N}-\mathrm{H}$ strain bond of an amide group and-OH group. The widespread shape of the peak evidences the presence of $-\mathrm{OH}$ groups of hydroxyproline.

ii. The next typical gelatin group is amide I. The absorption peak at a $1636-1697 \mathrm{~cm}^{-1}$ wavelength shows the $\mathrm{C}=\mathrm{O}$ strain, bending of the $\mathrm{N}-\mathrm{H}$ bond, and the $\mathrm{C}-\mathrm{N}$ strain. The $1697-1650 \mathrm{~cm}^{-1}$ area is the absorption area of the imide residue, which is a typical gelatin group [7].

iii. Typical gelatin absorption peaks on the II amide curve at a 1560$1335 \mathrm{~cm}^{-1}$ wavelength are caused by the deformation of $\mathrm{N}-\mathrm{H}$ bonds in proteins. This absorption region is associated with the breakup of tropokolagen into an $\alpha$-helix chain.

iv. The last specific absorption area is the third amide at a $1300-1200 \mathrm{~cm}^{-1}$ wavelength, which corresponds to the triple-helix (collagen) structure [7].

\section{pH value}

The mean $\mathrm{pH}$ level value of gelatin was $6.9 \pm 0.03$. The $\mathrm{pH}$ value of the gelatin samples met the standard gelatin type $\mathrm{B} \mathrm{pH}$ required by the GMIA, that is, between 5.0 and 7.5 [1] as shown in Table 1.

\section{Water content}

The sample gelatin had an average moisture content of $6.61 \%$. This value meets the SNI standard, which is maximum $16 \%$. Table 2 shows the data of water content of the gelatin sample obtained.

\section{Ash content}

The sample gelatin had an average ash content of $0.27 \%$. The value was within the range of ash values determined by the GMIA, that is, no more than $2 \%$ [1]. The ash content is determined by the hydrolysis process. The more the amount of minerals shed, the lower the ash content (Table 3).

\section{Viscosity}

According to the British standard, the gelatin viscosity values range from 1.5 to $7 \mathrm{cP}$. The sample gelatin viscosity value in our study ranged from $1.7490 \mathrm{cP} \pm 0.03 \mathrm{cP}$. This low value was due to heating above $40^{\circ} \mathrm{C}$. In addition, there is a possibility of degradation by proteolytic enzyme because of contamination by microorganisms. Furthermore, the analysis was done using unvalidated tools, and the test was not performed on standard gelatin. All these factors can influence the test results [1]. Table 4 shows the data of sample gelatin viscosity.

Table 1: Data of gelatin pH values

\begin{tabular}{llll}
\hline Sample & $\mathbf{p H}$ & Mean $\mathbf{p H}$ & Standard deviation \\
\hline Sample gelatin & & & \\
1 & 6.93 & 6.9 & 0.03 \\
2 & 6.9 & & \\
3 & 6.87 & & \\
Standard gelatin & & & 0.02 \\
1 & 6.32 & 6.3 & \\
2 & 6.3 & & \\
3 & 6.28 & & \\
\hline
\end{tabular}


Table 2: Data of sample gelatin water content

\begin{tabular}{|c|c|c|c|c|c|c|c|}
\hline Water content measurement & & & BS (g) & $\mathrm{BBK}+\mathrm{BS}$ (g) & BSK (g) & Water content $(\%)$ & Mean (\%) \\
\hline \multirow[t]{2}{*}{ Sample gelatin } & $\mathrm{I}$ & 17.6377 & 1.0007 & 18.6384 & 0.9365 & 6.42 & 6.61 \\
\hline & II & 18.0213 & 1.0003 & 19.0216 & 0.9322 & 6.81 & \\
\hline
\end{tabular}

BBK: Empty bottle weight, BS: Sample weight, BSK: Sample weight after drying

Table 3: Data of sample gelatin ash content

\begin{tabular}{lllllll}
\hline Ash content measurement & BCP (g) & BS (g) & BCP + BS (g) & BSK (g) & Ash content (\%) & Mean (\%) \\
\hline Sample gelatin & & & & & \\
I & 20.3165 & 2.0008 & 22.3173 & 22.3123 & 0.25 \\
II & 23.0179 & 2.0006 & 25.0185 & 25.0125 & 0.30 & 0.2749 \\
\hline
\end{tabular}

BCP: Empty porcelain dish weight, BS: Sample weight, BSK: Sample weight after drying

Table 4: Data of sample gelatin viscosity

\begin{tabular}{lllll}
\hline Viscosity & \multicolumn{2}{l}{$\begin{array}{l}\text { Viscosity } \\
\text { result (cP) }\end{array}$} & Mean (cP) & $\begin{array}{l}\text { Standard } \\
\text { deviation }\end{array}$ \\
\hline Sample gelatin & 1 & 1.7264 & 1.7490 & 0.03 \\
& 2 & 1.7853 & & \\
\hline
\end{tabular}

Table 5: Correlation between hydrolysis time and peak area of the derivative compound formed

\begin{tabular}{llll}
\hline Hydrolysis time (h) & \multicolumn{3}{l}{ Peak area of amino acid (mV/s) } \\
\cline { 2 - 4 } & Hydroxyproline & Glycine & Proline \\
\hline 22 & 1170768 & 3667552 & 2353964 \\
23 & 910732 & 2924464 & 2299293 \\
24 & 725199 & 1014852 & 939416 \\
\hline
\end{tabular}

\section{Optimum amino acid analysis}

Optimization of hydrolysis time

Hydrolysis of amino acid compounds was done with three-time variations, that is, 22,23 , and $24 \mathrm{~h}$. The $22 \mathrm{~h}$ hydrolysis time gave the largest peak areas of $1,170,768 \mathrm{mV} / \mathrm{s}$ for the amino acid hydroxyproline, $3,667,552 \mathrm{mV} / \mathrm{s}$ for the amino acid glycine, and 2,353,964 mV/s for the amino acid proline. The results show that an increase in hydrolysis time causes the peak area of the amino acid compound to slightly decrease (Table 5).

\section{Wavelength analysis}

The results of proline, glycine, and hydrolysoline compound analysis showed that the largest peak areas of $1,170,768 \mathrm{mV} / \mathrm{s}$ for hydroxyproline, $3,667,552 \mathrm{mV} / \mathrm{s}$ for glycine, and 2,353,964 mV/s for proline were obtained at an excitation wavelength of $265 \mathrm{~nm}$ and an emission wavelength of $320 \mathrm{~nm}$ (Table 6).

\section{Selection of mobile-phase composition}

Fabiani et al. [8] performed amino acid analysis with gradient elution with acetic acid (min/A\%) acetate buffer phase: $0 / 72,3 / 72,27 / 55$, $32 / 0,37 / 0,39 / 72$, and $47 / 72$. The flow rate was $1.0 \mathrm{~mL} / \mathrm{min}$. In the experiment, isocratic elution was performed thrice with acetate buffer (pH 4.2): Acetonitrile ratios of 55:45, 60:40, and 65:35 and a flow rate of $0.8 \mathrm{~mL} / \mathrm{min}$ to find the optimum condition for analysis. A 55:45 mobilephase composition was selected because it provided a short retention time, a high-resolution value, large theoretical plates, low HETP values, and a closer factor close to 1 (symmetrical) compared to the 60:40 and 65:35 mobile-phase compositions. For these latter two compositions, no complete glycine, proline, and hydroxyproline chromatogram data were obtained (Table 7).

\section{Selection of flowing phase motion}

Optimization of the phase motion was also carried out at different flow rates of $0.8,1.0$, and $1.2 \mathrm{~mL} / \mathrm{min}$. On the basis of the data obtained, the optimum flow rate was determined to be $0.8 \mathrm{~mL} / \mathrm{min}$ because it has a theoretical plate value, the HETP value was close to 0 , and the resolution value was high compared to flow rates of 1.0 and $1.2 \mathrm{~mL} / \mathrm{min}$ (Table 8).

\section{Test system compatibility}

The system suitability test should be performed before the selected analysis method is carried out with acetate: acetonitrile (55:45) exposure phases at a flow rate of $0.8 \mathrm{~mL} / \mathrm{min}$ used to analyze the amino acid derivative formed. Normally, there are variations in equipment and analytical techniques, so a system suitability test needs to be done to ensure that the final operational system is effective and delivers results appropriate to the objectives of the analysis.

The results of the repeatability test performed with as many as six injections are shown in Tables 9-11.

\section{Manufacture of calibration curves}

On the basis of the calculation of linear regression statistics, the equations of the calibration curve lines were as hydroxyproline: $y=1655.4 x+26,980$, glycine: $y=9351.2 x+30,431$, and proline: $y=5824.4 x+38,859, x$ is the concentration of hydroxyproline, glycine, or proline, and $y$ is the peak area of hydroxyproline, glycine, or proline. The data are shown in Tables 12-14.

\section{Linearity test}

The test of linearity with 1-20 ppm standard bovine gelatin yields correlation coefficient (r) values of 0.9981 for hydroxyproline, 0.9979 for glycine, and 0.9985 for proline. In this study, the formation of a good derivative compound between hydroxyproline, glycine, and proline with FMOC-Cl solution did not meet the linearity test standard $(\geq 0.9990)$. This was because the analysis was performed on a mixture of three derivatized amino acid solutions and the derivatization reagent did not deregulate completely for all three amino acids, resulting in a correlation coefficient ( $r$ ) of $<0.9990$ for the three amino acids being analyzed.

\section{Determination of $L O D$ and $L O Q$}

The LOD and LOQ of hydroxyproline, glycine, and proline were measured by statistically calculating the linear regression line of the calibration curve. For hydroxyproline, the LOD was obtained at a concentration of $0.900 \mathrm{ppm}$ and the LOQ at a concentration of $3.001 \mathrm{ppm}$. For glycine, the LOD was obtained at a concentration of $0.990 \mathrm{ppm}$ and the LOQ at a concentration of $3.301 \mathrm{ppm}$. For proline, the LOD was obtained at a concentration of $0.998 \mathrm{ppm}$ and the LOQ at a concentration of $3.327 \mathrm{ppm}$. From these results, we concluded that the LOQ does not 
Table 6: Correlation between variation of emission wavelength and peak area of the derivative compound formed

\begin{tabular}{lllll}
\hline Wavelength & & & \multicolumn{2}{c}{ Peak area of amino acid (mV/s) } \\
Excitation (nm) & Emission (nm) & & Hydroxyproline & Glycine \\
\hline 265 & 320 & 1170768 & 3667552 & 1718615 \\
& 325 & 650089 & 12353964 \\
& 330 & 328665 & 1117227 \\
\hline
\end{tabular}

Table 7: Correlation between retention time, number of theoretical plates, efficiency of columns, resolution, and chromatogram standard factor of bovine gelatin that has been hydrolyzed and derivatized with FMOC-Cl solution and changes in the acetic buffer:acetonitrile phase composition

\begin{tabular}{|c|c|c|c|c|c|c|c|c|c|c|c|c|c|c|c|}
\hline \multirow[t]{2}{*}{$\begin{array}{l}\text { Mobile-phase } \\
\text { composition }\end{array}$} & \multicolumn{3}{|c|}{ Retention time (min) } & \multicolumn{3}{|c|}{$\begin{array}{l}\text { Number of theoretical } \\
\text { plates }(N)\end{array}$} & \multicolumn{3}{|l|}{ HETP } & \multicolumn{3}{|c|}{ Resolution } & \multicolumn{3}{|c|}{ Tailing factor (Tf) } \\
\hline & Hyp & Gly & Pro & Hyp & Gly & Pro & Hyp & Gly & Pro & Hyp & Gly & Pro & Hyp & Gly & Pro \\
\hline $55: 45$ & 4.451 & 6.652 & 10.574 & 24369 & 35256 & 37793 & 0.0102 & 0.0070 & 0.0066 & 4.991 & 6.057 & 8.683 & 0.990 & 0.8979 & 1.000 \\
\hline $60: 40$ & 4.781 & - & - & 19039 & - & - & 0.0131 & - & - & 2.137 & - & - & 0.871 & - & - \\
\hline $65: 35$ & - & 6.711 & 10.813 & - & 17253 & 14783 & - & 0.0144 & 0.0169 & - & 5.450 & 6.952 & - & 1.016 & 1.458 \\
\hline
\end{tabular}

Table 8: Correlation between retention time, number of theoretical plates, efficiency of columns, resolution, and chromatogram standard factors of bovine gelatin that has been hydrolyzed and derivatized with FMOC-Cl solution and changes in the flow rate

\begin{tabular}{|c|c|c|c|c|c|c|c|c|c|c|c|c|c|c|c|}
\hline \multirow[t]{2}{*}{$\begin{array}{l}\text { Flow rate } \\
\text { (mL/min) }\end{array}$} & \multicolumn{3}{|c|}{ Retention time (min) } & \multicolumn{3}{|c|}{$\begin{array}{l}\text { Number of theoretical } \\
\text { plates (n) }\end{array}$} & \multicolumn{3}{|l|}{ HETP } & \multicolumn{3}{|l|}{ Tf } & \multicolumn{3}{|c|}{ Resolution } \\
\hline & Нyp & Gly & Pro & Нyp & Gly & Pro & Нyp & Gly & Pro & Hyp & Gly & Pro & Hyp & Gly & Pro \\
\hline 0.8 & 4.484 & 6.35 & 10.224 & 24369 & 35256 & 37793 & 0.0102 & 0.0070 & 0.0066 & 0.990 & 0.897 & 1.000 & 4.991 & 6.057 & 8.683 \\
\hline 1 & 4.427 & 6.462 & 10.598 & 22245 & 16987 & 22933 & 0.0112 & 0.0147 & 0.0109 & 0.998 & 1.032 & 1.094 & 3.846 & 4.972 & 8.373 \\
\hline 1.2 & 4.184 & 6.138 & 10.075 & 17816 & 9708 & 14989 & 0.0140 & 0.0257 & 0.0166 & 0.994 & 1.099 & 1.218 & 3.174 & 4.040 & 5.274 \\
\hline
\end{tabular}

Tf: Tailing factor

Table 9: Compliance test of the hydroxyproline system with a concentration of $10 \mu \mathrm{g} / \mathrm{mL}$

\begin{tabular}{|c|c|c|c|c|c|c|}
\hline Data & $\begin{array}{l}\text { Hydroxyproline } \\
\text { peak area }(\mathrm{mV} / \mathrm{s})\end{array}$ & $\begin{array}{l}\text { Retention time } \\
\text { (min) }\end{array}$ & $\begin{array}{l}\text { Tailing factor } \\
\text { (Tf) }\end{array}$ & $\begin{array}{l}\text { Number of theoretical } \\
\text { plates }(N)\end{array}$ & HETP & Resolution \\
\hline 1 & 50083 & 4.724 & 0.878 & 14656 & 0.0170 & 2.326 \\
\hline 2 & 51908 & 4.734 & 0.899 & 14444 & 0.0173 & 2.247 \\
\hline 3 & 51829 & 4.747 & 0.888 & 14353 & 0.0174 & 2.693 \\
\hline 4 & 51933 & 4.753 & 0.868 & 14657 & 0.0170 & 2.319 \\
\hline 5 & 51682 & 4.792 & 0.879 & 14213 & 0.0175 & 2.575 \\
\hline 6 & 51989 & 4.721 & 0.898 & 14587 & 0.0172 & 2.573 \\
\hline Mean & 51570.67 & 4.745 & 0.885 & 14485 & 0.01723 & 2.455 \\
\hline SD & 736.5277 & 0.0261 & 0.0122 & 180.1766 & $2.07 \times 10^{-3}$ & 0.180 \\
\hline$\% \mathrm{KV}$ & 1.42 & 0.55 & 1.38 & 1.24 & 1.19 & 7.36 \\
\hline
\end{tabular}

Table 10: Compliance test of the glycine system with a concentration of $10 \mu \mathrm{g} / \mathrm{mL}$

\begin{tabular}{|c|c|c|c|c|c|c|}
\hline Data & $\begin{array}{l}\text { Glycine peak area } \\
(\mathrm{mV} / \mathrm{s})\end{array}$ & $\begin{array}{l}\text { Retention } \\
\text { time (min) }\end{array}$ & $\begin{array}{l}\text { Tailing factor } \\
\text { (Tf) }\end{array}$ & $\begin{array}{l}\text { Number of } \\
\text { theoretical plates }(N)\end{array}$ & HETP & Resolution \\
\hline 1 & 174450 & 6.704 & 0.853 & 15926 & 0.01569 & 3.864 \\
\hline 2 & 178282 & 6.718 & 0.855 & 15899 & 0.01572 & 3.877 \\
\hline 3 & 176883 & 6.736 & 0.876 & 15912 & 0.01571 & 3.899 \\
\hline 4 & 171498 & 6.757 & 0.857 & 15890 & 0.01573 & 3.866 \\
\hline 5 & 177536 & 6.711 & 0.877 & 15940 & 0.01568 & 3.856 \\
\hline 6 & 179058 & 6.788 & 0.867 & 15931 & 0.01569 & 3.879 \\
\hline Mean \pm SD & $176284.5 \pm 2824.278$ & $6.735 \pm 0.031$ & $0.864 \pm 0.010$ & $15916.33 \pm 19.397$ & $0.01570 \pm 19 \times 10^{-4}$ & $3.873 \pm 0.015$ \\
\hline$\% \mathrm{KV}$ & 1.60 & 0.47 & 1.23 & 0.13 & 0.12 & 0.390 \\
\hline
\end{tabular}

enter the concentration range used in the calibration curve test. The calculation of the LOQ is related to linearity test results. In this study, linearity values in the mixed analysis of the three amino acids did not meet the requirements of the linearity test so as to influence the calculation of the LOD and LOQ.
Determination of levels

In this study, bovine hide samples were processed to extract bovine gelatin, which was then hydrolyzed to amino acids and derivatized with $1.5 \mathrm{mM}$ FMOC-Cl. The determination of amino acid levels was based on the linear regression equation. The average levels of hydroxyproline, 
Table 11: Compliance test of the proline system with a concentration of $10 \mu \mathrm{g} / \mathrm{mL}$

\begin{tabular}{llllll}
\hline Data & Proline peak area (mV/s) & $\begin{array}{l}\text { Retention } \\
\text { time (min) }\end{array}$ & Tailing factor (Tf) & $\begin{array}{l}\text { Number of } \\
\text { theoretical plates }(\boldsymbol{N})\end{array}$ & $\begin{array}{l}\text { HETP } \\
\text { Resolution }\end{array}$ \\
\hline 1 & 136382 & 10.804 & 0.968 & 16477 & 0.0151 \\
2 & 133956 & 10.850 & 0.956 & 16211 & 0.0154 \\
3 & 135241 & 10.857 & 0.945 & 16421 & 0.0152 \\
4 & 136489 & 10.898 & 0.923 & 16121 & 0.0155 \\
5 & 136950 & 10.877 & 0.978 & 16342 & 0.0152 \\
6 & 133193 & 10.857 & 0.921 & 16788 & 0.0148 \\
Mean \pm SD & $135368.5 \pm 1518.424$ & $10.857 \pm 0.0314$ & $0.948 \pm 0.023$ & $16393.33 \pm 233.9117$ & $0.0152 \pm 2.15 \times 10^{-4}$ \\
$\%$ KV & 1.12 & 0.28 & 2.46 & 1.42 & $5.720 \pm 0.0379$ \\
\hline
\end{tabular}

Manufacture of calibration curve, linearity test, and LOD and LOQ

Table 12: Test data of calibration curve, LOD, and LOQ for hydroxyproline derivatized with FMOC-Cl solution under selected conditions

\begin{tabular}{llllll}
\hline Concentration (ppm) & $\begin{array}{l}\text { Hydroxyproline } \\
\text { peak area }(\mathbf{m V} / \mathbf{s})\end{array}$ & $\mathbf{y i = a + b x}$ & $\mathbf{( y - y i ) ^ { 2 }}$ & $\mathbf{S}(\mathbf{y} / \mathbf{x})^{\mathbf{2}}$ & \multicolumn{2}{c}{$\mathbf{S ( y / x )}$} & \\
\hline 1 & 28552 & 28635.4 & 6955.56 & 246748.6406 & 496.738 \\
2 & 30100 & 30920.8 & 673712.6 & & \\
4 & 33143 & 33601.6 & 210314 & & \\
5 & 35132 & 35257 & 15625 & & \\
10 & 44957 & 43534 & 2024929 & & \\
20 & 59523 & 60088 & 319225 & & \\
\hline
\end{tabular}

Table 13: Test data of calibration curve, LOD, and LOQ for glycine derivatized with FMOC-Cl solution under selected conditions

\begin{tabular}{|c|c|c|c|c|c|c|c|}
\hline Concentration (ppm) & $\begin{array}{l}\text { Glycine peak } \\
\text { area }(\mathrm{mV} / \mathrm{s})\end{array}$ & $y i=a+b x$ & $(y-y i)^{2}$ & $S(y / x)^{2}$ & $S(y / x)$ & LOD (ppm) & LOQ (ppm) \\
\hline 1 & 44627 & 39782.2 & 23472087 & 9531137.261 & 3087.254 & 0.990 & 3.301 \\
\hline 2 & 51107 & 49133.4 & 3895097 & & & & \\
\hline 4 & 61971 & 67835.8 & 34395879 & & & & \\
\hline 5 & 72445 & 77187 & 22486564 & & & & \\
\hline 10 & 127680 & 123948 & 13927824 & & & & \\
\hline 20 & 217504 & 217455 & 2401 & & & & \\
\hline
\end{tabular}

Table 14: Test data of calibration curve, LOD, and LOQ for proline derivatized with FMOC-Cl solution under selected conditions

\begin{tabular}{|c|c|c|c|c|c|c|c|}
\hline Concentration (ppm) & $\begin{array}{l}\text { Proline peak } \\
\text { area }(\mathrm{mV} / \mathrm{s})\end{array}$ & $y i=a+b x$ & $(y-y i)^{2}$ & $S(y / x)^{2}$ & $S(y / x)$ & LOD (ppm) & LOQ (ppm) \\
\hline 1 & 41472 & 44683.4 & 10313090 & 3754169.755 & 1937.568 & 0.998 & 3.327 \\
\hline 2 & 53543 & 50507.8 & 9212439 & & & & \\
\hline 4 & 61478 & 62156.6 & 460498 & & & & \\
\hline 5 & 67696 & 67981 & 81225 & & & & \\
\hline 10 & 99256 & 97103 & 4635409 & & & & \\
\hline 20 & 154334 & 155347 & 1026169 & & & & \\
\hline
\end{tabular}

*LOD: Limit of detection, LOQ: Limit of quantification

Table 15: Determination of hydroxyproline levels in cured bovine gelatin samples derivatized with FMOC-Cl solution under selected conditions

\begin{tabular}{|c|c|c|c|c|}
\hline Concentration (ppm) & Hydroxyproline peak area in bovine gelatin samples $(\mathrm{mV} / \mathrm{s})$ & Content (ppm) & Content (\%) & Mean \pm SD (\%) \\
\hline \multirow[t]{3}{*}{10} & 29213 & 1.3489 & 13.49 & $13.50 \pm 0.052$ \\
\hline & 29208 & 1.3459 & 13.46 & \\
\hline & 29225 & 1.3562 & 13.56 & \\
\hline
\end{tabular}

Table 16: Determination of glycine levels in cured bovine gelatin samples derivatized with FMOC-Cl solution under selected conditions

\begin{tabular}{llll}
\hline Concentration (ppm) & Glycine peak area in bovine gelatin samples (mV/s) & Content (ppm) & Content (\%) \\
\hline 10 & 53989 & 2.5192 & 25.19 \\
& 53820 & 2.5012 & $25.10 \pm 0.0906$ \\
& 53917 & 2.5115 & 25.12 \\
\hline
\end{tabular}


Table 17: Determination of proline levels in cured bovine gelatin samples derivatized with FMOC-Cl solution under selected conditions

\begin{tabular}{lcccc}
\hline Concentration (ppm) & Proline peak area in bovine gelatin samples (mV/s) & Content (ppm) & Content (\%) & Mean \pm SD (\%) \\
\hline 10 & 47174 & 1.4277 & 14.28 & $14.28 \pm 0.116$ \\
& 47244 & 1.4397 & 14.40 \\
\hline
\end{tabular}

glycine, and proline in cured bovine gelatin samples derivatized with FMOCCl solution were $13.50 \pm 0.05 \%, 25.11 \pm 0.09 \%$, and $14.28 \pm 0.11 \%$, respectively the results were close to the literature [1]. The data of levels sample are shown in Tables 15-17.

\section{CONCLUSION}

In this study, we found that bovine gelatin isolated and extracted from bovine hide with $2 \%$ sodium hydroxide for $48 \mathrm{~h}$ gave a rendement value of $8.757 \%(w / w)$, which was confirmed by functional group analysis using FTIR. Optimum conditions for the analysis of the determination of hydroxyproline, glycine, and proline levels in bovine gelatin using HPLC with a fluorescence detector were $\lambda_{\mathrm{ex}}=265 \mathrm{~nm}$ and $\lambda_{\mathrm{em}}=320 \mathrm{~nm}$; a YMC-Triart ${ }^{\circledR}$ C18 column (column length $250 \mathrm{~mm}$, inner diameter $4.6 \mathrm{~mm}$, and particle size $5 \mu \mathrm{m}$ ); acetate: acetonitrile buffer phase (55:45); and a $0.8 \mathrm{~mL} / \mathrm{min}$ flow rate. The optimum conditions for bovine gelatin hydrolysis included $\mathrm{HCl}$ with heating for $22 \mathrm{~h}$ at $110^{\circ} \mathrm{C}$. The hydroxyproline, glycine, and proline levels obtained for analysis in bovine gelatin samples were $13.50 \pm 0.05 \%, 25.11 \pm 0.09 \%$, and $14.28 \pm 0.11 \%$, respectively.

\section{CONFLICTS OF INTEREST}

All authors have none to declare.

\section{REFERENCES}

1. Gelatin Manufacturer's Institute of America. Standard Methods for the Testing of Edible Gelatin. America: Gelatin Manufacturers Institute of America, Inc; 2012.

2. Setiawati IH. Quality Characteristics of Chemical Physics Gelatin Skin Red Snapper (Lutjanus sp) as Process of Acid Treatment. Bogor: Institut Pertanian Bogor; 2009.

3. Mazumder R, Allamneni Y, Firdous SM, Parya H, Chowdhury AD. Formulation, development and in-vitro release effects of ethyl cellulose coated pectin microspheres for colon targeting. Asian J Pharm Clin Res 2013;6:138-44.

4. Farshid A, Lakshmi CS. Formulation of nanoparticles of anti-migraine drugs triptans by coacervation method. Asian J Pharm Clin Res 2017;10:122-8.

5. Princely S, Saleem BN, Nandhakumar S, Dhanaraju MD. Controlled delivery of antiretroviral drug-loaded cross-linked microspheres by ionic gelation method. Asian J Pharm Clin Res 2016;9:264-71.

6. Hafidz RM, Yaakob CM, Amin I, Noorfaizan A. Chemical and functional properties of bovine and porcine skin gelatin. Int Food Res J 2011;18:813-7.

7. Puspawati NM, Simpen IN, Miwada IN. Isolation of Gelatin from Broiler Chicken Skin and Functional Group Characteristics with FTIR Spectrophotometry. Denpasar: Department of Chemistry, Faculty of Animal Sciences, Universitas Udayana; 2012.

8. Fabiani A, Versari A, Parpinello GP, Castellari M, Galassi S. Highperformance liquid chromatographic analysis of free amino acids in fruit juices using derivatization with 9-Fluorenylmethyl-Chloroformate. J Chromatogr Sci 2002;40:14-8. 